\title{
Hubungan Antara Bobot Badan Awal dan Bobot Badan Akhir Itik Hibrida Jantan dan Betina
}

\section{The Relationship Beetween Body Weight and Body Weight Gain Early Ducks Hybrid Males and Females}

\author{
Dwi Ainur Rahmah ${ }^{1}$, Drh. Muridi Qomaruddin, $\mathrm{MM}^{2}$, Ratna Kumala Dewi, S.Pt, MMG, M.Eng ${ }^{3}$ \\ ${ }^{1}$ Mahasiswa Fakultas Peternakan \\ ${ }^{2}$ Dosen Pembimbing Utama \\ ${ }^{3}$ Dosen Pembimbing Pendamping \\ Program Studi Peternakan \\ Fakultas Peternakan, Universitas Islam Lamongan (UNISLA)
}

\section{RINGKASAN}

Banjarejo Kecamatan Sukodadi Kabupaten Lamongan, mulai tanggal 01Mei sampai dengan 28 Mei 2016. Tujuan dari penelitian ini adalah untuk mengkaji hubungan antara bobot badan awal dan bobot badan akhir itik hibrida jantan dan betina yang meliputi bobot badan awal dan bobot badan akhir. Materi yang digunakan dalam penelitian ini adalah Itik hibrida jantan dan betina masingmasing 30 ekor umur 5 minggu. Data dianalisis menggunakan analisa regresi korelasi sederhana. Hubungan bobot badan awal dan bobot badan akhir jantan dan betina. Pakan yang digunakan adalah tepung roti, bekatul halus, jagungdan konsentrat. Kandang yang digunakan adalah kandang kelompok sebanyak 12 unit kandang setiap battery berisi lima ekor itik dan dilengkapi dengan tempat pakan, dan tempat minum. Pemberian pakan dilakukan dua kali sehari pagi dan sore, pemberian minum secara adlibitum. Guna mengetahui perbedaan antar perlakuan menggunakan Uji analisa regresi korelasi sederhana. Variabel yang diamati adalah bobot badan awal itik hibrida jantan, bobot akhir itik hibrida jantan, bobot awal itik hibrida betina, dan bobot akhir itik betina hibrida. Hasil penelitian menunjukan bahwa pada itik jantan yaitu $\bar{y}=966,25+1,02 x$ dapat diartiakan kenaikan bobot badan sebesar 1,02 gram bobot terendahnya 966,25 gram yang dipelihara selama 28 hari serta koefisien

korelasi sebesar 0,37 koeefisien determinasi $13,7 \%$. Pada itik betina $\bar{y}=1054,6+0,65 \mathrm{x}$ dapat diartiakan kenaikan bobot badan sebesar 0,65 gram bobot terendahnya 1054,6 gram sehingga pada betina tidak terdapat hubungan yang positif. Itik jantan $F$ Hitung lebih besar dari $F$ tabel $(P>0,05)$ memberikan pengaruh yang beda nyata pada itik hibrida betina $F$ Hitung lebih kecil dari $F$ tabel sehingga tidak terdapat pengaruh karena hasilnya tidak beda nyata. Berdasarkan hasil penelitian dapat disimpulkan bahwa pada perhitungan analisa regresi pada itik jantan terdapat pengaruh yang beda nyata pada level $5 \%$.

\begin{abstract}
The research was carried out on a farm owned by Mr. Rudi is Ducks Farm Banjarejo Village,Lamongan City, began on 01 Mey 2016 up to 28 Mey 2016. The goal of this research is to find out the relationship between body weight and weight loss end early duck hybrid males and females that comprise the initial body weight and weight loss. A variable that observed is the weight of a body of early ducks hybrid male, the weight of the end of a teal hybrid male, the weight of the beginning of the female, ducks hybrid and the weight of the end of a teal female hybrid. Research results show that the male ducks $\mathrm{F}$ Count greater than $\mathrm{F}$ table $(\mathrm{P}>0.05)$ gives a different influence on real ducks hybrid females F Calculate is smaller than the table so there is no F influence because the result is not a real difference. Based on the research can be concluded that on ducks male there are influence real difference in levels of $5 \%$.
\end{abstract}

Key word: duck hybrid, body weight, sex

\section{PENDAHULUAN}

Di Indonesia, ternak itik merupakan salah satu ternak unggas yang cukup potensial, terutama produksi telurnya. Ada tiga bangsa unggas yang menjadi sumber telur di Indonesia yaitu: ayam, itik dan burung puyuh. Sebanyak $16 \%$ kebutuhan telur di Indonesia 
dihasilkan oleh ternak itik. Berdasarkan dari data Dinas Peternakan propinsi Jawa Timur menyebutkan bahwa populasi ternak itik pada tahun 2001 sebanyak 2.316.205 ekor dan pada tahun 2003 meningkat menjadi 2.333.851 ekor (Ditjennak, 2001 dalam Suharno, 2005).

Itik atau dalam istilah bahasa Jawa disebut bebek dimana terus menerus didomestikasi oleh manusia hingga itik yang dipelihara sekarang disebut Anas domesticus (ternak itik). Nenek moyang itik berasal dari Amerika Utara merupakan itik liar (Anas moscha) atau Wild mallard (Wakhid, 2013).

Itik Hibrida merupakan itik tipe pedaging hasil persilangan antara Itik Peking dengan Itik Khaki Campbell. Jika bobot badan awal itik baik,maka bobot akhir itik juga baik. Itik Peking adalah itik yang berasal dari Cina, setelah mengalami perkembangan di Inggris dan Amerika itik Peking menjadi sangat populer. Itik Peking merupakan itik dwiguna,itik Peking betina sebagai itik petelur dan itik Peking jantan sebagai itik pedaging yang sangat baik. Bibit itik ini dapat diperoleh di daerah Sumatera Utara. Itik Peking tata laksana pemeliharaannya tidak berbeda dengan pemeliharaan itik tiktok baik bentuk kandang, jenis pakan, pemilihan bibit maupun cara perawatan yang dilakukan.

Awalnya DOD (Day Old Duckling) jantan dianggap kurang berharga, terutama pada peternak itik petelur. Akibatnya, harga DOD (Day Old Duckling) itik jantan menjadi jauh lebih murah dibandingkan dengan itik betina. Namun, tren konsumsi daging itik yang terus menerus meningkat membuat itik jantan dari jenis itik petelur dipelihara secara khusus sebagai itik pedaging. Penggunaan itik jantan sebagai itik pedaging memiliki keunggulan karena harga bibit cukup murah dan ketersediaanya cukup banyak. Salah satu jenis itik jantan pedaging yang khusus dikembangkan sebagai pejantan pedaging adalah itik jenis Hibrida Raja. Jenis itik ini dikembangkan oleh Balai Pembibitan Terak Unggul Kambing Domba dan Itik (Wakhid,2013). Bobot badan awal pada itik yang baik akan menghasilkan bobot akhir yang baik pula dengan pantauan bahwa itik dengan keadaan baik tidak terserang penyakit (Khaleka, 2015).
Ditinjau dari aspek ekonomi, biaya pakan itik sangat tinggi mencapai

$70 \%$ dari total biaya produksi. Kebiasaan peternak menggunakan pakan produksi pabrik atau pakan komersial yang menghabiskan $60-70 \%$ biaya produksi. Karena biaya pakan yang sangat tinggi inilah, maka diperlukannya pengkajian terhadap penggunaan bahan pakan dalam memenuhi kebutuhan zat-zat makanan ternak untuk mencapai efisiensi produksi, salah satunya dengan cara penggunaan Jagung, tepung roti, BR 1,dan bekatul halus. Pakan dasar yang digunakan dalam penelitian ini adalah pakan campuran yang terdiri atas konsentrat, tepung roti, jagung dan bekatul halus dengan perbandingan $20: 10: 20: 50$. Kandungan protein $12 \%$ dedak halus, $4,32 \%$ kandungan energi 2,400 kkal/kg, konsentrat kandungan protein $23 \%$ kandungan lemak 4\%, dan kandungan protein tepung roti $6 \%$, Energi $3838 \mathrm{kkal} / \mathrm{kg}$ (Rahmah,2016).

Itik

\section{MATERI DAN METODE}

Itik Hibrida yang digunakan dalam penelitian ini itik hibrida jantan dan betina berumur 5 minggu masing-masing berjumlah 30 ekor.

\section{METODE PENELITIAN}

Penelitian dilakukan dengan percobaan menggunakan itik hibrida jantan dan betina yang diberi identitas individu. Dalam hal ini peneliti bermaksud mencari hubungan antara jenis kelamin itik hibrida (jantan dan betina) dengan peningkatan bobot badan itik. Untuk mencari hubungan tersebut, maka peneliti membandingkan antara bobot awal dan bobot akhir itik hibrida jantan dan betina pada usia 5 minggu sampai 8 minggu.

\section{VARIABEL YANG DIAMATI}

Variabel yang diamati dalam penelitian ini meliputi :

a. Bobot badan awal itik hibrida jantan

b. Bobot akhir itik hibrida jantan

c. Bobot badan awal itik hibrida betina

d. Bobot akhir itik hibrida betina

ANALISIS DATA 
Data yang diperoleh dianalisis dengan menggunakan analisis korelasi regresi sederhana mencari hubungan dengan cara membandingkan bobot badan awal dan bobot badan akhir itik hibrida jantan pada usia 5 minggu sampai 8 minggu dengan rumus :

$$
\begin{aligned}
& \bar{y}=\mathrm{a}+\mathrm{bx} \\
& \mathrm{a}=\sum \mathrm{Y}-\mathrm{b} \sum \mathrm{X} \\
& \mathrm{b} \quad=\frac{\mathrm{N}\left(\sum \mathrm{XY}\right)-\sum \mathrm{X} \sum \mathrm{Y}}{N \sum X i^{2}-\left(\sum X\right)^{2}} \\
& \quad=\sum_{\mathrm{i}=1}^{\mathrm{t}} \mathrm{Yi}^{2}-\frac{1}{n}\left(\sum Y i\right)^{2} \\
& \mathrm{JK}_{\text {Total }} \quad=\mathrm{b}\left(\sum \mathrm{XY}-\left(\sum \mathrm{X} \sum \mathrm{Y}\right) / \mathrm{n}\right) \\
& \mathrm{JK}_{\text {Regresi }} \\
& \mathrm{JK}_{\text {Galat }} \quad=\mathrm{JK}_{\text {Total }}-\mathrm{JK}_{\text {Regresi }} \\
& \mathrm{KT}_{\text {Regresi }} \quad=\mathrm{JK}_{\text {Regresi }} / 1 \\
& \mathrm{KT}_{\text {Galat }} \quad=\mathrm{JK}_{\text {Galat }} / \mathrm{db}_{\text {Galat }} \\
& \mathrm{F}_{\text {Hitung }} \quad=\mathrm{KT}_{\text {Regresi }} / \mathrm{KT}_{\text {Galat }}
\end{aligned}
$$

Analisa Korelasi

$$
\begin{array}{ll}
\mathrm{R} & =\mathrm{JK}_{\text {Regresi }} / \mathrm{JK}_{\text {Total }} \\
\mathrm{r} & =\sqrt{R}
\end{array}
$$

\section{HASIL DAN PEMBAHASAN}

\section{Bobot Badan Awal}

Jumlah bobot badan awal pada itik jantan dan betina seperti yang terlampir pada Lampiran 1 dan Lampiran 5 terdapat perbedaan bobot badan, bobot badan itik jantan cenderung lebih rendah dibanding itik betina. Dengan kisaran rata-rata bobot badan itik jantan 404 gram dan betina 437 gram. Hal ini sesuai dengan penelitian yang dilakukan oleh Heriyanto, (2013) bahwa "bobot badan awal itik hibrida betina cenderung lebih tinggi dibandingkan bobot badan akhir itik hibrida betina dikarenakan daya stres terhadap lingkungan paska panen lebih tinggi".

\section{Bobot Badan Akhir}

Jumlah bobot akhir yang terjadi antara itik jantan dan itik betina seperti yang terlampir pada Lampiran 1 dan Lampiran 5 menunjukan bahwa ada perbedaan antara bobot badan akhir itik jantan dan itik betina. Bobot badan itik jantan jauh lebih tinggi dibandingkan itik betina. Hal ini sesuai dengan yang dikemukakan Wakhid, (2013) bahwa “ itik jantan cenderung pertumbuhan lebih cepat dan mencapai bobot tinggi dibandingkan itik betina".

\section{Hubungan Antara Bobot Badan Awal dan Bobot Akhir Itik Hibrida Jantan}

Dari perhitungan Analisa Regresi Pertambahan Bobot Badan Itik Jantan Lampiran 2 di dapatkan hubungan badan awal dan bobot akhir itik hibrida jantan yaitu $\bar{y}=$ $966,25+1,02 x$ yang dapat di artikan bahwa bobot itik hibrida jantan akan di ikuti kenaikkan bobot sebesar 1,02 gram dari bobot terendahnya 966,25 gram.

Setelah diketahui bentuk hubungan bobot badan awal dan akhir itik hibrida jantan maka dapat dilanjutkan dengan menguji dapat atau tidak bentuk hubungan $\bar{y}=$ $966,25+1,02 x$, dari hasil sidik regresi pada Lampiran 4 di peroleh hasil yang beda nyata dengan nilai $F$ hitung sebesar 4,46 dan dibandingkan dengan $\mathrm{F}$ tabel signifikasi $0,05 \%$ sebesar 4,20 dan signifikasi $0,01 \%$ sebesar 7,64 sehingga diketahui bahwa $\mathrm{F}$ hitung lebih besar dari $\mathrm{F}$ tabel,pada taraf 5\% dan 1\% maka persamaan regresi yang telah di dapatkan yaitu $\bar{y}=966,25+1,02 \mathrm{x}$ dapat digunakan sebagai penduga untuk memprediksi hubungan bobot awal dan akhir itik hibrida jantan. Hal ini sesuai dengan dikemukakan oleh (Kwanchai A. Gomez dan arturo A. Gomez, 1995). Bahwa:

Ada hubungan antara bobot

$1=\quad$ badan awal dan bobot badan akhir itik Hibrida Jantan.

Berdasarkan hasil koefisien korelasi (r) pada Lampiran 4 dapat diketahui nilai korelasi sebesar 0,37 sehingga diketahui bahwa terdapat hubungan yang positif antara variabel bobot badan awal dan bobot akhir itik hibrida jantan.

Koefisien determinasi adalah hasil kuadrat dari korelasi yang ditunjukkan untuk 
mengetahui nilai pengaruh antara bobot badan awal dan akhir itik hibrida jantan sehingga setelah diketahui koefisien korelasi sebesar 0,37 dan selanjutnya dikuadratkan maka koefisien determinasi sebesar 13,70\%, sehingga dapat diartikan bahwa hubungan bobot badan awal dan bobot badan akhir sebesar $13,70 \%$ sedangkan sisanya $76,30 \%$ dipengaruhi faktor lain.

Tabel 4.3 Hasil Penelitian Analisa Regresi Hubungan antara Bobot Badan Awal

Bobot Badan Akhir Itik Jantan

\begin{tabular}{|c|c|c|c|c|c|c|}
\hline \multirow{3}{*}{$\begin{array}{l}\quad \mathrm{S} \\
\text { umber } \\
\text { Kerag } \\
\text { aman }\end{array}$} & \multirow{3}{*}{$\begin{array}{l}\text { eraj } \\
\text { at } \\
\text { Beb } \\
\text { as }\end{array}$} & \multicolumn{2}{|c|}{$\mathbf{J}$} & \multirow[b]{3}{*}{$\begin{array}{l}\text { itun } \\
\text { g }\end{array}$} & \multirow{2}{*}{\multicolumn{2}{|c|}{$\begin{array}{c}\mathrm{F} \\
\text { Tabel }\end{array}$}} \\
\hline & & umlah & uadra & & & \\
\hline & & $\begin{array}{l}\text { Kuadr } \\
\text { at }\end{array}$ & $\begin{array}{l}\mathrm{t} \\
\text { Teng } \\
\mathrm{ah}\end{array}$ & & $\begin{array}{l}, 0 \\
5 \\
\end{array}$ & $\begin{array}{l}0 \\
1 \\
\end{array}$ \\
\hline $\mathrm{R}$ & & 1 & & & & \\
\hline egresi & & 66464 & $\begin{array}{l}6646 \\
4\end{array}$ & ,46 & $\begin{array}{l}, 2 \\
0\end{array}$ & $\begin{array}{l}6 \\
4\end{array}$ \\
\hline alat & 8 & $\begin{array}{l}04275^{1} \\
2,7\end{array}$ & $\begin{array}{l}7241 \\
, 16\end{array}$ & & $\begin{array}{l}(* \\
)^{*}\end{array}$ & \\
\hline otal & 9 & $\begin{array}{l}1 \\
20921 \\
6,7\end{array}$ & & & & \\
\hline
\end{tabular}

Sumber tabel : Data primer diolah ( 2016 )

F Hitung > F Tabel (*) ada hubungan berbeda nyata.

\section{Hubungan Antara Bobot Badan Awal dan Bobot Badan Akhir Itik Hibrida Betina}

Dari perhitungan Analisa Regresi Pertambahan Bobot Badan Itik Betina Lampiran 6 yaitu $\bar{y}=1054,6+0,65 x$ yang dapat di artikan bahwa bobot itik hibrida betina akan di ikuti kenaikkan bobot sebesar 0,65 gram bobot terendahnya 1054,6 gram.

Setelah diketahui bentuk hubungan bobot badan awal dan akhir itik hibrida betina maka dapat dilanjutkan dengan menguji dapat atau tidak bentuk hubungan $\bar{y}=$ $1054,6+0,65 x$, dari hasil sidik regresi pada Lampiran 8 di peroleh hasil yang tidak beda nyata dengan nilai $\mathrm{F}$ hitung sebesar 0,97 dan dibandingkan dengan $\mathrm{F}$ tabel signifikasi $0,05 \%$ sebesar 4,20 dan signifikasi $0,01 \%$ sebesar
7,64 sehingga diketahui bahwa $\mathrm{F}$ hitung kecil dari $\mathrm{F}$ tabel dalam taraf $\mathrm{F}$ tabel $0,05 \%$ dan $0,01 \%$, maka persamaan regresi yang telah di dapatkan yaitu $\bar{y}=1054,6+0,65 \mathrm{x}$ tidak dapat digunakan sebagai penduga untuk memprediksi hubungan bobot awal dan akhir itik hibrida betina. Hal ini tidak sesuai dengan yang dikemukakan oleh (Kwanchai A. Gomez dan arturo A. Gomez, 1995) bahwa "jika F hitung < $\mathrm{F}$ tabel maka tidak ada hubungan berbeda nyata"

Berdasarkan hasil koefisien korelasi (r) pada Lampiran 8 dapat diketahui nilai korelasi sebesar 0,18 sehingga diketahui bahwa tidak terdapat hubungan yang positif antara variabel bobot badan awal dan bobot akhir itik hibrida betina.

Koefisien determinasi adalah hasil kuadrat dari korelasi yang ditunjukkan untuk mengetahui nilai pengaruh antara bobot badan awal dan akhir itk hibrida betina sehingga setelah diketahui koefisien korelasi sebesar 0,18 dan selanjutnya dikuadratkan maka koefisien determinasi sebesar 3,30\%, sehingga dapat diartikan bahwa hubungan bobot badan awal dan bobot badan akhir sebesar 3,30\% sedangkan sisanya $96,70 \%$ dipengaruhi faktor lain.

Tabel 4.4 Hasil Penelitian Analisa Regresi Hubungan antara Bobot Badan Awal dan

Bobot Badan Akhir Itik Betina

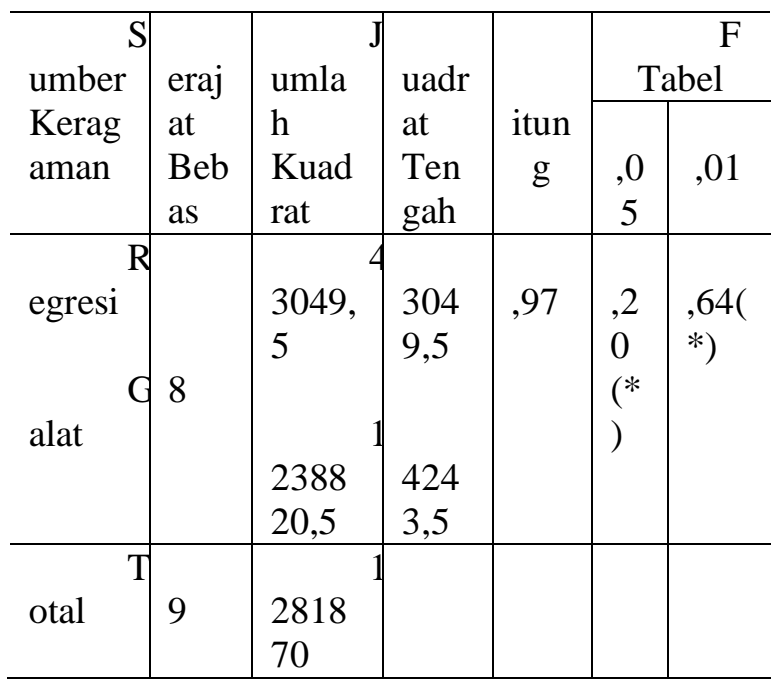

Sumber tabel : Data primer diolah ( 2016 ) 
$\mathrm{F}$ hitung < F tabel $(*)$ tidak ada hubungan berbeda nyata.

\section{Hubungan Antara Jenis Kelamin dengan Peningkatan Bobot Badan dan Hubungan Antara Jenis Kelamin dengan Konversi Pakan}

Hasil penelitian ini telah menunjukkan bahwa ada hubungan antara jenis kelamin dengan konsumsi pakan pada itik hibrida, ada hubungan antara jenis kelamin dengan peningkatan bobot badan pada itik hibrida, dan ada hubungan antara jenis kelamin dengan konversi pakan pada itik hibrida. Yang didasarkan pada tabel 4.1 dan 4.2.

Sesuai dengan pendapat Wakhid,(2013) bahwa jumlah pakan yang dikonsumsi berpengaruh terhadap pertambahan bobot badan, dimana dengan konsumsi pakan yang rendah akan menghasilkan pertambahan bobot badan yang rendah, dan konsumsi pakan yang tinggi akan menghasilkan pertambahan bobot badan yang tinggi pula.

Menurut hasil penelitian Windhyarti (2003), pertumbuhan itik lokal jantan asal Tasikmalaya dan Garut cenderung lebih besar dibandingkan dengan itik betina. Konsumsi pakan itik jantan lebih tinggi dari betina, tetapi konversi pakan itik jantan lebih baik daripada itik betina. Sedangkan menurut Wahyu (2004) bobot badan itik lokal jantan asal Bali berbeda dengan betina, umumnya jantan mencapai berat $1,8-2 \mathrm{~kg}$, sedangkan betina hanya 1,6$1,8 \mathrm{~kg}$.

Hal ini juga sama pada jenis itik hibrida tertentu misalnya Itik Peking Jantan disilangakan dengan Itik betina lokal seperti Itik Campbell dan Itik Alabio, dimana umumnya jantan mencapai berat $1,8-2 \mathrm{~kg}$, sedangkan betina hanya $1,6-1,8 \mathrm{~kg}$.

Dengan demikian jenis itik hibrida yang diamati dalam penelitian ini terbukti jenis kelaminnya memiliki pengaruh terhadap konsumsi pakan, peningkatan bobot badan, dan konversi pakan. Baik itik betina maupun itik jantan memiliki ukuran yang hampir berbeda. Oleh sebab itu peternak dapat membudidayakan itik hibrida ini untuk dijual dagingnya dengan membedakan perlakuan betina dengan jantan, baik pada saat membeli $D O D$, saat pemeliharaan,dan pemberian takaran konsumsi pakan.

\section{KESIMPULAN DAN SARAN}

\section{KESIMPULAN}

Berdasarkan hasil penelitian dan pembahasan dapat dibuat beberapa kesimpulan, antara lain:

1. Berdasarkan hasil penelitian terdapat hubungan yang positif antara variabel bobot badan awal dan bobot akhir itik hibrida jantan dengan nilai korelasi sebesar 0,37 .

2. Berdasarkan hasil penelitian diketahui bahwa ada hubungan akan tetapi tidak signifikan antara variabel bobot badan awal dan bobot akhir itik hibrida betina dikarenakan nilai korelasi hanya sebesar 0,18 .

3. Berdasarkan hasil penelitian maka sebaiknya memelihara itik hibrida jantan lebih menguntungkan dibandingkan itik hibrida betina.

\section{SARAN}

Adapun beberapa saran yang dapat diberikan terkait dengan hasil penelitian ini adalah keberhasilan beternak itik hibrida ini sebaiknya memperhatikan dalam pemilihan bibit yang berkualitas dan sebaiknya disarankan memelihara itik hibrida jantan.

\section{DAFTAR PUSTAKA}

Anggorodi, R., 1990. Ilmu Makanan Ternak Umum, Gramedia. Jakarta

Anonymous, 2000. Budidaya Ternak Itik. Dinas Peternakan Prop. DIY Proyek Peningkatan Sumber Daya Sarana dan Prasarana Peternakan Tahun Anggaran 1999/2000

Anonymous. 2003. Keunggulan Itik Mojosari sebagai Itik Petelur. Diakses tanggal 5 juni 2016 dari http://202.158.78.180/agritech/dkij012 0. df.

Hartadi H., S. Reksohadiprojo, AD. Tilman. 1997. Tabel Komposisi Pakan Untuk Indonesia. Cetakan Keempat, Gadjah Mada Uivesity Press, Yogyakarta.

Heriyanto, D., 2013. Skripsi Analisa Bobot Badan Awal dan Akhir Itik Hibrida Betina. Universitas Brawi-jaya Press. Malang.

Kwanchai A. Gomez dan arturo A. Gomez. 1995. Prosedur Statistik Untuk 
penelitian Pertanian. Penerbit

Universitas Indonesia.

Khaleka,N. 2015. Beternak Itik Tanpa Bau

Tanpa Angon. Arcitra. Jogjakarta

Marhiyanto B. 2004. Beternak Bebek Darat

Petelur. Gitamedia Press. Surabaya

Nazir, M. 1988. Metode Penelitian. Ghalia Indonesia. Jakarta

NRC., 1985. Nutrien Requirement of Domestic. No. 2. Nutrein Requrement of Swine National Academy of Science. Washington DC.

Purnamaningsih. 2010.Panduan Beternak Itik. Agromedia Pustaka. Jakarta

Rahmah D. 2016. HASIL ANALISA PROKSIMAT PAKAN JADI DAN ROTI. Lab Unair. Surabaya

Ranto dan M. Sitanggang. 2005. Panduan Lengkap Beternak Itik. Agromedia Pustaka. Jakarta

Scott, M.L. and M. Dean. 1991. Nutrition and Management of Ducks. M.L. Scott of Itchaca. New York.

Suharno, A. 2005. Panduan Beternak Itik Secara Intensif. Penerbit Penebar Swadaya.

Supriyadi, 2010. Panduan Lengkap Itik. Penebar Swadaya. Jakarta

Sutawi. 2007. Kapita Selekta Agribisnis Peternakan. Universitas Muhammadiyah Malang Press. Malang

Syukur, D.A. 2007. Beternak Itik. Leaflet Dinas Peternakan Lampung. Diakses tanggal 7 juni 2016 dari http://disnakkeswanlampung.go.id/brosur/itik.pdf.

Wahyu, J. 2004. Ilmu Nutrisi Unggas. Gajah Mada University Press. Yogyakarta

Windhyarti. 2003. Berternak Itik Tanpa Air. Penebar Swadaya. Jakarta.

Wakhid,A. 2013. Peternak Itik, Agromedia Pustaka. Jakarta 